\title{
Habib, Samra. (2019). We Have Always Been Here: A Queer Muslim Memoir. Toronto: Viking Press.
}

Reviewed by: Yaseen El-hakim, MacEwan University

Samra Habib’s book, “We Have Always Been Here: A Queer Muslim Memoir,” is based on a personal account of her queer Muslim upbringing detailing the discord between her individuality and religion. In revealing her experiences as a child in Pakistan, her family seeking refuge in Toronto, her adaptation to Canadian culture, and the gradual discovery of her identity in her adulthood, Habib recounts a palpable portrayal of a queer individual's road to self-acceptance and self-expression. Her book describes an environment that imposes conformity through traditional and familial means, making it difficult for the denigrated to realize their independence.

Habib's account of her childhood addresses women's roles in society. Her relationship with her mother, who had submitted to Ahmadi Muslim society's expectations of mere servitude, is critical; those years' innocence was coupled with realistic struggles of Ahmadi Muslims ruled under a repressive Pakistani government. She would be too young to understand, let alone take up a role that was not gendered, while her mother believed that "as a woman, fertility, purity, and beauty were the only currencies she could exchange for a better life" (p. 17). Everyone her family socialized with would engage in normalities like Friday prayer, and when she strayed from her preordained path, she would be punished. Her family acted as her sovereign, her perceived ideal 
for comparison, so when leaving for Canada amid the heightened discrimination against Ahmadi Muslims, she submitted to the move.

Canadian culture introduced Habib to novel family dynamics, roles, feelings, and experiences. Instead of being comprehensive and socially integrated with her age group, she could not understand the other girls' crushes on boys and often spent time alone. Her family swiftly felt hard times as they struggled to make enough to earn a comfortable living. Consequently, she was compelled to take on a role of more responsibility. She was the finest English speaker in her family and would have to translate important documents for her parents. She would earn money by doing odd jobs and working at a bargain store, further subverting the norms and values of Ahmadi Muslim culture. Western individualism was taking precedence over her childhood. What was once normal in Pakistan was now abnormal and scorned; bullies would mock her accent and nationality. Nonetheless, Canada's multiculturalism made her optimistic that she could integrate and be comfortable with her culture.

Upon entering high school, the author felt a sense of solidarity. Girls like her from Somalian to Pakistani families had to balance their familial values with their perceptions. Things like her arranged marriage and her parents' amusement with her academic arts achievements clashed with developing her personal identity. Her arranged marriage to Nasir would act as a way her controlling parents could keep watch of her. The relationship got to the stage where "[she] truly believed that harming [her]self was the only way [she] could escape [her] circumstances" (p.101). Ending the marriage was the first time she broke free of collective norms. Shamed by the Islamic community, tensions were high at this moment and her parental relationship felt fragile. In 
response, Habib decided to start living with Peter and to pursue higher education. Her guilt, however, compelled her to allow her family back into her life, with Habib entering into her second marriage before becoming twenty years old. The hivemind was restored, pressuring her into another marriage, and the apprehensiveness surrounding her sexuality was increasingly direct as "[s]ex was a chore, like paying bills or washing dishes" (p. 114). Amid her unfulfilling heterosexual sex life, she developed her fashion and photography interests, which were supplemented by the obscure and engaging people she met. Meanwhile, Habib reconnected with her mother, who became more permissive despite her daughter's decisions and lifestyle. Her father, however, was indifferent to her relationship with a non-Muslim, yet the marriage offered a route back into creating a healthier familial relationship.

As her personal life changed, Habib was emboldened to make stable connections in her professional sphere. Her colleagues provided guidance to experience a queer world she had not yet discovered. These experiences of gay nightlife spawned an epiphany that she was indeed a lesbian and had been denying herself that self-expression. At the mercy of this denial was an ailing marriage to Peter that was attempting a renaissance. The inevitable divorce would produce hope for a fully realized reconciliation with her family. This is apparent when she phones her mother to notify her of her sudden trip to Tokyo and is met with resignation and acceptance. Thereafter, marked her first time identifying herself as a queer woman, the first embrace of her true identity, and first sexual encounter with a woman. A burden to her though was the shunning of the LGBTQ in her faith. El Farouk Khaki's mosque in Toronto offered sanctuary and rediscovery of Islam for queer Muslims. Habib’s relationship with Islam was salvaged through the kinship she felt with the 
mosque's diverse patrons. It was a joyful reclamation of her identity where "for the first time [she] was witnessing a version of Islam [she] could be a part of' (p. 169). Religion offered stability in life, and to be rejected from it made her life even more convoluted. Queer visibility was now her primary goal with ventures, including her photo pieces and articles for news corporations like The Guardian. Amid her constantly shifting life circumstances, her family was increasingly supportive. Her keynote address to the University of North Carolina proved to be a steppingstone for her career and one that promoted public perception of the LGBTQ. Although she acknowledges Islam is indifferent to the LGBTQ, she knew where she stood in the world and what her calling now was.

Samra Habib's memoir is liberal in terms of its presentation and language. The book transcends societal boundaries as the writer is candid, wanting people to learn from her story. The book's transparency is its most salient and digestible aspect. However, the most brilliant element of the work is how it presents Islam and queer sexuality in opposition. In her early childhood in Pakistan, she is unaware of her sexual identity, purpose in society, and the norms and values thrust upon her seem ill-fitting. In her young adult life, it is the reverse; instead, she is far from being in touch with her religion as she spends time in gay bars in Tokyo and familiarizes herself with her sexual identity. Throughout the book, her religion and sexuality grapple with each other. Each never coming together on her terms, and ultimately, both compromises to unite. Islam rarely talks about homosexuality as though it is taboo, and Habib has a refreshing perspective in dealing with a sensitive subject.

Regarding the book's drawbacks, there are minor issues concerning broader implications for Islam itself. While Habib's piece is about the queer perspective, views of Islam could be 
negatively affected. People may misconstrue the messages Habib is attempting to convey and use it as a means to justify Islamophobia and excessive criticism of Islam. For instance, her father is the primary male character active in the book and is portrayed for the majority of it as a conservative, patriarchal, and controlling figure. Other male Muslim characters are portrayed similarly, Nasir for example. Nevertheless, it may be unavoidable due to the emphasis being on the LGBTQ narrative and Islam's populous genuinely being hateful towards queer people. Additionally, a new dimension would have been added to the book if sibling relationships had more detail and development. Still, the book is about her developmental challenges, so focusing on her and her parent's relationship is a given. The objective is to dispel irrational notions of the queer lifestyle and shed light on a group of largely neglected people.

This sentiment might be reassuring to someone in a similar position. Many queer Muslims exist and likely have gone through horrible experiences of oppression executed in service of traditional norms. In Pakistan and Canada's Islamic communities where the author grew up, queer Muslims were scarcely recognized. It is easy for a topic like the vulnerability of the queer in a conservative religion to be concealed. Simultaneously, people similar to her parents should not be blamed for how they raised their child as they seem to have used their own lives as templates for virtuous parenting. In her acknowledgements, she thanks all the friends and colleagues who helped her develop her sense of identity. Her account of her life events is well-written and has given a voice to forgotten members of society.

The academic audience that would find this intriguing book relevant would be those concerned with childcare, immigrant families, and the LGBTQ+. Specific professions would not 
be limited to teachers, social workers, child psychologists, civil rights lawyers, immigration consultants, researchers, and scholars. The traumas described in this book may service professionals in refining information and strategies regarding society's marginalized. The book is essential for anyone who is deals with immigrants, the sexually persecuted, and essentially anyone who feels rejected by society. 